\title{
THE
}

\section{Op-Ed Writing Assignment in Supply Chain Management Courses}

Hee Yoon Kwon

Jiayuan Zhang

University of Rhode Island

Koray Özpolat

University of Rhode Island, koray@uri.edu

Yufang Lin

Adolf K.Y. Ng

Follow this and additional works at: https://digitalcommons.uri.edu/cba_facpubs

The University of Rhode Island Faculty have made this article openly available.

Please let us know how Open Access to this research benefits you.

This is a pre-publication author manuscript of the final, published article.

Terms of Use

This article is made available under the terms and conditions applicable towards Open Access

Policy Articles, as set forth in our Terms of Use.

\section{Citation/Publisher Attribution}

Kwon, HY, Zhang, J, Özpolat, K, Lin, Y, Ng, AK. Op-Ed Writing Assignment in Supply Chain Management Courses. Decision Sciences Journal of Innovative Education. 2020; 00: 00- 00. https://doi.org/10.1111/ dsji. 12225

Available at: https://doi.org/10.1111/dsji.12225

This Article is brought to you for free and open access by the College of Business at DigitalCommons@URI. It has been accepted for inclusion in College of Business Faculty Publications by an authorized administrator of DigitalCommons@URI.For more information, please contact digitalcommons-group@uri.edu. 


\title{
Op-ed writing assignment in supply chain management courses
}

\author{
ABSTRACT \\ Newspaper op-eds, dedicated to commentary essays from outside of a newspaper, function as a \\ platform for the public to exchange opinions. We designed an op-ed writing assignment as part \\ of a semester-long course research project in global supply chain management. Student teams \\ conducted research, presented their work in the classroom, and wrote an op-ed to be submitted to \\ local or regional newspapers. This teaching brief describes the implementation of the assignment \\ at a northeast U.S. university's global supply chain management course. The learning goals of \\ this assignment are: 1) to educate students on how to write an op-ed, which is a novel and \\ unfamiliar writing style for most students; and 2) to educate students on how to publish their \\ opinions in a newspaper, which includes how to interact with journalists. The insights on \\ benefits, challenges, and improvements of the op-ed assignment are discussed at the end of the \\ manuscript. An alternative implementation case of the op-ed writing assignment in a Canadian \\ University, as well as insights from the alternative implementation, are also provided. \\ Subject Areas: Projects, Pedagogy, Supply Chain Management.
}

\section{INTRODUCTION}

The "deepest responsibility" of the newspaper, Oakes wrote, was "the same responsibility ... that the college has for its students - the responsibility of making them think." Thus, a fundamental purpose of the editorial page was "to question, to debunk." "Diversity of opinion is the lifeblood of democracy," Oakes contended in a 1954 speech. "The minute we begin to insist that everyone think the same way we think, our democratic way of life is in danger." John B. Oakes 


\section{(N.Y. Times editorials editor that created the op-ed page), Requoted from}

\section{Socolow (2010)}

The outside commentary page of a newspaper, commonly referred to as op-eds for being on the “opposite of editorial page", publish opinion essays on various topics, even if the opinion is not aligned with the newspaper's own. Op-eds in newspapers, thus, function as "a forum for the exchange and clash of ideas...covering a whole broad range of intellectual interests" (Socolow, 2010, p. 286). The op-ed page offers greater opportunity for expressing one's opinions and ideas to writers and thinkers who have no institutional connection with the media, even if their opinions are contrary to the editorial team's views (The New York Times, September 21, 1970, p.42).

We demonstrate a case of integrating op-ed writing to upper division supply chain management (SCM) courses at a northeast U.S. university. The op-ed writing assignment was given as part of a semester-long team research project. Student teams were required to conduct independent research on emerging SCM topics, deliver a 30-minute presentation in the classroom, and write an op-ed article on their assigned topic. The learning goals of the op-ed writing assignment are: 1) to educate students on how to write an op-ed, which is a novel and unfamiliar writing style for most students; and 2) to educate students on how to publish their opinions in a newspaper, which includes how to interact with journalists. Channeling students to express their opinions on contemporary business/SCM topics for the benefit of the community, this project also fosters students' critical thinking capabilities and sense of social responsibility. These contributions are aligned with the goal of nurturing active thinkers that participate in the process of democracy by speaking up in the public fora on issues that are important to their communities and professions, thus returning benefits of their university education to the public. 
We also demonstrate an alternative implementation of the op-ed writing assignment with a different approach for the topics. Instead of an array of contemporary SCM topics, the alternative implementation uses a case study based on a local supply chain disruption.

\section{LITERATURE REVIEW}

The benefits of incorporating op-ed writing in coursework have been demonstrated by various scholars. J. C. Hall and Podemska-Mikluch (2015) showed that op-ed writing is the most conducive way of encouraging students to be sensible and active members of civil society, as well as active advocates of economic reasoning. Schneller (2016) demonstrated that op-ed writing can be used to help students develop and articulate their personal perspectives about environmental and sustainability issues. Calavita and Krumholz (2003) identified op-ed writing as highly visible public participation that can inform and invigorate teaching and help engage students. Poronnik and Moni (2006) found that although students perceived op-ed writing to be challenging, they also believed their ability to effectively communicate their knowledge to nonprofessional audiences in writing was improved after explicit teaching and feedback.

Our implementation of op-ed writing to coursework is based on active learning pedagogy. Active learning is defined as any instructional method that engages students in the learning process (Prince, 2004). It requires students to do meaningful learning activities and think about what they are doing (Prince, 2004; Bonwell \& Eison, 1991). Bonwell and Eison (1991) summarized the literature on active learning and concluded that it leads to better student attitudes and improvements in student thinking and writing. Under this pedagogy, the Just-InTime (JIT) exercise with Mega Blocks by Ashenbaum (2010) is one of many teaching 
innovations proposed in operations and supply chain management (Ellis, Goldsby, Bailey, \& Oh, 2014; Hill \& Baker, 2016; Brau, Gardner, Webb, \& Mcdonald, 2019).

Bringing the active learning pedagogy into the social responsibility domain, Özpolat, Chen, Hales, Yu, and Yalcin (2014) required students to design public service announcements in support of USAID's smart compassion campaign to address unsolicited material donations. Wentzel (1991), upon reviewing the literature on social responsibility and academic achievement, argues that "student social responsibility is not only a valued outcome in and of itself, but that it can be instrumental in the acquisition of knowledge and development of cognitive abilities (p.16)". Kingston, Maccartney, and Miller (2014) identify social responsibility as an integral element of preparing students for global citizenship.

The implementation of our op-ed writing assignment is also based on team-based learning (TBL) (Parmelee \& Michaelsen, 2010; Sweet \& Michaelsen, 2012; Khansari \& Coyne, 2018). TBL focuses on small group interaction more heavily than any other commonly used instructional strategy (Michaelsen \& Sweet, 2008). With TBL, group work is central to exposing students to, and improving their ability to apply, course content (Michaelsen \& Sweet, 2008). Students work in small groups to finish the op-ed writing assignment, and the interaction between students will improve their ability to apply the course content.

The remainder of this brief consists of a detailed layout of the project in the two classes at a northeast U.S. university. An alternative case of the project implemented in a Canadian university is also provided. After the discussion of the case, we discuss the insights from various sources, along with specific suggestions for improved implementation. 


\section{PROJECT OVERVIEW}

The implementation of the op-ed writing assignment took place in the spring semester of 2019 at a northeast U.S. university. Two sections of an upper division SCM course were taught by the same instructor on Tuesdays and Thursdays, at 09:30 AM (Section 1) and 11:00 AM (Section 2) for 75 minutes. The op-ed writing assignment was part of a semester-long team research project, which required student teams to (i) conduct independent research on an emergent SCM topic, (ii) make a 30-min. class presentation, and (iii-a) write an op-ed on the topic with the team's opinion and submit it to a local/regional media outlet or (iii-b) write a 10-page research report. The class presentation served as a demonstration of independent learning and research as well as team coordination. The op-ed/report writing complemented the research project as the written deliverable. The research project had 30 percent weight in the student's final grade -25 percent on self-initiated learning and class presentation, and 5 percent on the op-ed writing/research report assignment.

In the first week of the semester, the instructor assigned students into teams of four, ensuring that every team had at least two different business majors. From a menu of 12 topics provided by the instructor, student teams identified their top three choices and were assigned to one. The research topics were related to either cutting-edge supply chain technologies or contemporary global supply chain management. A full list of research topics is provided in Table 1.

Insert Table 1 Here

In both sections, students were required to conduct a thorough research in their assigned topic. The primary deliverable of the research was the classroom presentation, in which teams 
presented their research to their colleagues for 30 minutes. The op-ed writing assignment complemented the research project as a written deliverable.

In Section 1, all teams were required to write an op-ed of 600-700 words as a written deliverable of the research project. In Section 2, teams had a choice between an op-ed of 600-700 words and a 10-page team research report. The research report was meant to be a written summary of their presentation, including their research process and findings. Because the instructor deemed this to be a relatively simple task, it was determined that the time and effort required for writing a 600-700-word op-ed, which was a novel writing style for most students, was comparable to that required for a 10-page research report. Interestingly, however, all teams of Section 2 opted for the op-ed writing assignment. All other conditions were kept identical between sections. At the end of the semester, questionnaires were distributed to students for data collection. The questionnaire included qualitative and quantitative items.

\section{Participants}

Section 1 had 44 students, while Section 2 had 49. All enrolled students were either juniors or seniors, and most were SCM or Marketing majors. Among the enrolled students, 56 were male and 37 were female. Table 2 shows the demographic breakdown of the students.

Insert Table 2 Here

\section{Milestones}

In both sections, team presentations on research topics were spread out from the third week to the last week of classes. A first draft of the op-ed was due in the $9^{\text {th }}$ week. The TA provided feedback within a week, and the updated second draft was due in the $11^{\text {th }}$ week. Another round of review and feedback was provided in the same week, and a revised final draft was due in the $12^{\text {th }}$ week. After a brief last feedback in the same week, teams were required to submit the op-ed 
to a local/regional newspaper by the end of the $13^{\text {th }}$ week. If the first target newspaper rejected the manuscript, teams submitted to another newspaper by the end of the $14^{\text {th }}$ week. Table 3 provides a list of milestones.

Insert Table 3 Here

\section{In-Class Introduction of Op-ed Writing}

While the topic selection and classroom presentation portion of the team research project was guided and graded by the principal instructor who is an associate professor, the op-ed writing portion was guided and graded by a graduate teaching assistant (TA) at the doctoral level. The TA made a 20-minute in-class presentation in the fourth week of the semester, introducing the purpose, function, and format of op-ed writing. The detail of the op-ed writing assignment within the team research project was also covered. Three online articles (Omang, 2008; T. Hall, 2013; Duke University, 2019) on op-ed writing guidelines were shared with the students on the syllabi and during TA presentation. Also, the TA introduced a few op-ed articles written and published by previous semester's students to demonstrate not only the structure of an op-ed but also the feasibility of student publications.

\section{Grading}

Regarding what constitutes a good op-ed article, we referred to resources available online (Omang, 2008; T. Hall, 2013; Duke University, 2019) to identify several important components: a strong hook to grasp the reader's attention at the beginning, a strong argument with personal voice, demonstrated personal connections to the readers, plentiful evidence supporting the argument, specific recommendations or policy suggestions, and a concsise writing with 600-750 words. Combining these components with the university's standards for academic writing 
assignments (e.g. grammar, punctuation, structure, etc.), we created an op-ed grading rubric (Appendix A).

\section{Survey Administration}

An Institutional Review Board (IRB) approved survey was conducted in the last class session of the semester. The survey contained three open-ended qualitative questions, as well as eight quantitative questions adapted from related studies (Sun, Flores, \& Tanguma, 2012; Erzurumlu

\& Rollag, 2013; Hill \& Baker, 2016; Li, Marsh, \& Rienties, 2016; Stansbury \& Earnest, 2017; Ryan \& Deci, 2018). The analysis used 34 returned surveys from Section 1 and 33 returned surveys from Section $2(N=67)$.

\section{ASSESSMENT OF THE ASSIGNMENT}

\section{The Experience: TA Review, Submissions, and Publications}

As specified in Table 3, student teams submitted their first draft op-ed in MS Word format at the end of the $9^{\text {th }}$ week. The TA received the submissions via e-mail from each team and provided written feedback in the form of edits and electronic memos on the MS Word document. The first draft feedback was predominantly on conformity to the op-ed format, since the majority of teams were following the familiar academic report format. A specifically prevalent issue was the lack of opinion in the writing, since summarizing their research project alone tended to take up most of the 600-to-700-word limit. Another widespread issue was the lack of a strong hook in the first paragraph that grasps the attention of the reader. The first round of review and feedback for the 23 manuscripts took the TA a full week to review, and the student teams had a week to work on the revision and resubmit the second. The TA also posted general feedback in the Announcement 
board of the learning management system (LMS), along with instructions for the second draft submission. TA's first general feedback is provided in Appendix B.

The second draft submission saw significant improvement in several teams, yet many teams were still stuck at the academic format. Some made a transition into a news article, establishing relevance between the topic and local/regional/national implications but still lacking a strong opinion. Prevalent issues in the second round also included the first paragraph not containing the main point, ambiguous and broad suggestions and solutions, and too much detailed information. The second round of review and feedback for the 23 manuscripts took the TA four days to review, and the student teams had four days to work on the revision and resubmit the final draft to the TA. The TA also posted a general feedback in the Announcement board of the LMS, along with instructions for the final draft submission. Preparing students for the final stage, the instructor and TA provided a list of local media outlets for the students to consider. The second general feedback is provided in Appendix C. At this time, the TA also provided a sample cover letter for submission to the editor. The sample cover letter is provided in Appendix D.

The final draft submission saw significant advances in many team's manuscripts, and the reviews were finished in one day. The TA gave teams specific instructions for formatting their manuscripts and submitting them to one local/regional newspaper within 24 hours. Students were instructed not to reveal the fact that their manuscript is part of a course assignment but take full ownership of the submission. The initial submission instructions are provided in Appendix E. A week after the initial submission, the TA posted instructions for withdrawal and resubmission to another newspaper for those teams with no acceptance. Students were instructed to send a letter of withdrawal to the editor if the editor didn't respond to their initial submission within 12 days. 
The TA graded each team's op-ed manuscript based on the op-ed grading rubric developed from multiple resources on op-ed writing (Omang, 2008; T. Hall, 2013; Duke University, 2019) and the university's academic writing rubric. The average score of Section 1 was 90.1 out of 100, and that of Section 2 was 92.8. The average of both sections at 91.4 signifies that the first learning goal of educating students how to write an op-ed was achieved.

14 out of 23 teams initially submitted to a prime regional newspaper. Three teams initially submitted to a regional business newspaper. Five other teams submitted to local newspapers, and one submitted to the university newspaper. Out of the initial submissions, three teams were accepted and published in the business newspaper and two local newspapers. The second submission (after withdrawal from the first newspaper) was dispersed to various local newspapers. Three more teams published in two local newspapers. We provide hyperlinks to the published student op-eds in Appendix F. Seven student op-ed publications in local and regional newspapers and a practitioner journal signifies the second learning goal of educating students how to publish their opinions in a newspaper was achieved.

\section{Qualitative Survey}

Three qualitative questions were asked to explore student perceptions on the greatest takeaway and the greatest challenge from the op-ed writing assignment, as well as their feelings for the oped writing assignment. Two techniques and procedures were adopted from Kock, Verville, and Garza (2007) to code the qualitative responses. The first technique identified patterns across the textual data. Responses were categorized into several patterns, the frequencies of the patterns were calculated as percentages (Miles \& Huberman, 1994; Yin, 2017). The second technique employed was content analysis. We applied manifest (semantic) content analysis and latent (inferred) content analysis (Wilson, 1989) on the patterns identified 
by the first method. The next sections discuss the results of the qualitative data analysis of the textual responses for the questions on the greatest takeaway, greatest challenge, and feelings towards the op-ed writing assignment.

\section{Takeaway}

After iterative rounds of discussions among the authors, responses to the question on the greatest takeaway were coded into six categories (Voice, Learning, Community, Publication, Style, and Others). The Voice category includes illustrative quotations on how the op-ed writing assignment helps students to express their opinions on a news outlet. The Learning category includes illustrative quotations on how the assignment helps them learn the topics deeper. The Community category includes illustrative quotations on how the assignment helps them connect and contribute to their community. The Publication category includes illustrative quotations on how the assignment helps them learn how to publish on a newspaper. The Style category includes illustrative quotations on learning how to write an opinion column, which for many of our students was a novel style of writing. All those quotations that don't fall into the five categories specified above were coded into the Others category. Table 6 summarizes the illustrative quotations of each category.

Insert Table 4 Here

\section{Challenge}

Responses to the question on the greatest challenge were coded into seven categories (Teamwork, Opinion forming, Style, Publication, Relevance, Iterative review process, and Others). The Teamwork category includes illustrative quotations on the challenge of working as a team to write an op-ed article. The Opinion forming category includes illustrative quotations on the challenges of building a firm opinion. The Style category includes illustrative quotations on 
the challenges of learning a new writing style. The Publication category includes illustrative quotations on the challenges of being accepted for publication on a newspaper. The Relevance category includes illustrative quotations on the challenges of making meaningful connections between the generic topic and the regional context. The Iterative review process category includes illustrative quotations on the challenges of going through the TA-guided revision process. All the quotations that don't fall into the six challenge categories specified above were coded into the Others category. Table 7 summarizes the illustrative quotations for each category.

\section{Insert Table 5 Here}

\section{Feelings}

The responses to the question asking how students feel about the op-ed writing assignment were first categorized for overall feeling, in Positive (57.81\%), Neutral (26.56\%), and Negative (15.63\%). To validate the categorization, the authors ran a sentiment analysis with R-studio. The responses were compared to the "bing" and "nrc" lexicon, which identify specific, predetermined words in responses as criteria for categorization. The "bing" lexicon categorizes each response into a Positive-Negative dichotomy (Figure 1), identifying 37 positive responses and 5 negative responses. The "nrc" lexicon categorizes each response to one of ten categories (Figure 2), identifying 79 positive responses (Positive, Trust, Joy, Anticipation, and surprise) and 20 negative responses (Negative, Fear, Sadness, Anger, and Disgust). These results indicate that students feel overwhelmingly positive toward the op-ed writing assignment.

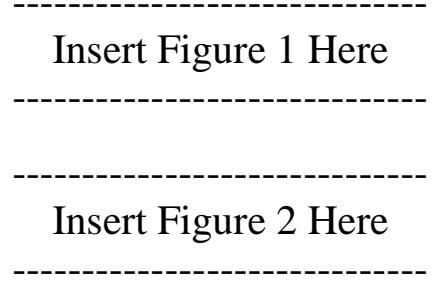


Finally, in our survey we asked quantitative questions about student's experience with the op-ed writing assignment. Responses indicate their level of agreement with the eight statements in Table 8 on a 5 -point Likert scale $(1=$ Strongly Disagree to $5=$ Strongly Agree $)$. The percentage of students that agree or strongly agree to each statement is shown in the far-right column of Table 8. In sum, over half of students surveyed agree that working on the op-ed as a course assignment helps them to learn the topics in more depth (e.g. $63 \%$ of the students agree and strongly agree that writing the op-ed improved their understanding on the research topic)

Insert Table 6 Here

\section{DISCUSSION}

Designed as part of an active learning research project, the op-ed writing assignment offered many benefits to students. It is our observation that this assignment helped students develop their own voice on a topic related to their profession, learned a new way of writing, practiced teamwork, and learned how to publish on a newspaper. In this section, we discuss the benefits of this assignment as well as how it can be further improved. Additionally, we present an alternative implementation of the op-ed writing assignment based on a single case study rather than an array of topical research, which was done in the same semester in a university in Canada.

\section{Voice}

Students expressed greatest excitement in realizing that they can also participate in the public opinion exchange through writing op-eds. The op-ed writing assignment, with its instructional elements, supplemented the research project by promoting an outlet for contributing student's learning to the community and society. Many students mentioned that they realized it was so easy to submit an op-ed and their own opinion can be valuable. Writing an op-ed brings students 
out of the typical role of receiving knowledge, enabling and empowering them to express and construct their own opinions and solutions.

\section{Learning}

Student comments on their takeaway on learning indicate that writing an op-ed enabled them to take a deeper look at the topic that they would have otherwise disregarded, and to apply the knowledge making connections between classroom knowledge and reality. These remarks are aligned with the benefits of active learning: a deeper understanding of course concepts and a positive attitude toward learning (Salemi, 2002).

\section{Novelty}

Many students expressed excitement in doing something for the first time and learning a new writing style and structure that aims to grab public attention. The difference in format, e.g. heavier focus on the opinion than on information, and the ability to use first person, were mentioned as takeaways.

\section{Teamwork}

Learning from the interaction with peers is one of the major benefits of active learning. Thus, the research project and the op-ed writing assignment were designed as team tasks. The teamwork component is also intended to enhance the student's soft skills of exchanging opinions among teammates, making compromises and negotiating a common ground, and collaborating for a common goal. The instructor and TA witnessed students actively engaging in team discussions and debates through the entire course of the semester, and the resulting team presentations and op-eds were indicators of success for such goals. However, the process for the students was apparently not easy. Student comments indicated hardship in forming a single strong opinion among four individuals with diverse views. Multiple student responses explicitly suggested 
assigning less people to a team - teams of two instead of four or five, or even making op-ed writing an individual assignment.

\section{Timing}

Activities for the op-ed writing assignment were concentrated in the second half of the 14-week semester, whereas team research presentations were spread across those 14 weeks. Thus, the disparity of timeline may cause several issues. First, student teams that finished their research presentation earlier in the semester may be detached from their topic by the time they were required to write the op-eds. Second, the grading TA must process multiple waves of overwhelming load of student manuscripts within a short period of time. Third, the resulting student manuscripts tend to be concentrated to a few news outlets, potentially biasing the editor's decision towards rejecting most of them. Introducing the op-ed writing project early in the semester and initiating each team's writing process after their presentation may enhance retention of student interest, avoid concentrated workload for the grader, and enhance the chance of being accepted for publication.

\section{Choice}

Teams of Section 2 had a choice between writing an op-ed and writing a 10-page research paper. All teams opted for the op-ed. When asked the primary reason for choosing the op-ed over the research paper, $87 \%$ of individual students responded that the sheer volume of a 10-page research report vs. a 700-word op-ed was the primary factor in their decision. If the intention is to provide students with real choices that promote self-initiation and autonomy, clearly communicating the true expected workload of all alternatives, along with all of the details for the task milestones, would be crucial.

\section{Social Competition, Stress, and Grading}


In previous implementations, the U.S. instructor observed that openly complementing successful first round publication in class or rewarding publications with better grades imposed unintended stress and anxiety on some students which were so far unsuccessful in publishing their op-eds. Since the op-ed writing assignment is considered a supplementary activity to the research project for promoting social responsibility and improving writing skills, we decided to keep the grade weight at $5 \%$ and not to discriminate published and unpublished teams in grading. The 5\% grade was entirely dependent on the quality of the manuscript (according to the rubric), punctuality in the iterative review process and submission to newspapers, and professional conduct in interacting with the TA and editors.

\section{Professional Benefits}

Several students from the U.S. university that successfully published their op-eds on a newspaper uploaded a link to the on-line article on their LinkedIn account. Considering the characteristic of LinkedIn as a professional social networking service, publishing their op-eds on a newspaper appears to be perceived as a significant achievement.

Students sign the op-ed submissions as "Univ. of ..... students majoring in ......", and published op-eds bring publicity to the department, college, and university. Students not only take pride in educating the public on a timely business topic, but also provide exposure to the university through publishing op-eds. A department head at the U.S. university commented: “oped is a wonderful opportunity for students to practice their skills in writing publicly and is also very encouraging for them to speak their thoughts. It also is good for marketing the program."

The implementation of the op-ed writing assignment demonstrated so far is based on an array of topics in contemporary events and technologies and their impact on global supply chains. In the following section, we demonstrate an alternative implementation of the assignment 
on a case study project. In a university in southern Canada, the op-ed writing assignment was implemented as a deliverable of a case study of local rail and port facility disruption.

\section{Alternative Implementation with Case Study}

At the Canadian university, two different upper-division SCM courses were taught by the same instructor. Course $1(n=31)$ took place twice a week on Mondays and Wednesdays for 75 minutes, while Course $2(n=39)$ took place once a week on Thursdays for 75 minutes. Table 7 shows the demographic breakdown of the students.

\section{Insert Table 7 Here}

In Course 1, students were assigned to teams of three, while in Course 2 students were assigned to teams of four. In both courses, student teams were required to conduct a case study of the rail and port facility disruption in a town in southern Canada, where the university is located. Teams presented their case study for 30 minutes during class time and wrote an op-ed article of 600-700 words.

The purpose of the alternative implementation was to provide a different perspective of the op-ed writing assignment using a case study on a local topic of high interest. Working on a topic that is directly related to the university's community seems to have an impact on student enthusiasm. Local students that were familiar with the local supply chain facility disruption were more active in the learning process, including searching for more background knowledge, proposing innovative and practical solutions, completing their share of work, and learning the course materials relevant to the case. Their perception of contributing to their own community may have encouraged them to participate more in the teamwork since they are driven by the 
passion for improving their own community's environment and economy. Additionally, incorporating the op-ed writing assignment in a case study of a local issue provides international students a chance to learn about the current events in the local community and voice their opinions from a different perspective.

\section{CONCLUSION}

This teaching brief presents the implementation of an op-ed writing assignment in an undergraduate SCM course, complementing a team research project on emergent SCM topics. We have found this assignment to be effective in teaching students how to write an op-ed, which entails learning a novel writing style for most students. We also found the assignment to be competent in teaching students how to publish their opinions in a newspaper, which includes the review process and interaction with journalists and newspaper editors.

We have found this assignment to be beneficial to our students by engaging them in the process of forming an opinion with strong grounding in the local/regional communities and participation in the public forum of policy debates and discussions. Many students expressed, via survey and verbal comments, their excitement in learning that they, too, can have a voice in important global issues. By offering cutting edge business technology or contemporary global supply chain perspectives to the general public, this op-ed writing assignment serves as a social responsibility project for students as well. Finally, the project could also offer career benefits to the students by fortifying their critical thinking capabilities and collaborative skills, making them more valuable employees.

The op-ed writing assignment can be improved in various ways, including providing a broader choice of topics and teaming options. Utilizing the campus Writing Center (Kovach, 
Miley, \& Ramos, 2012) or collaborating with a professional journalist (Poronnik \& Moni, 2006) would help streamline the review process and improve the overall quality of student manuscripts. Further, op-ed writing may be offered to students as an optional assignment, allowing them to work in smaller teams. 


\section{REFERENCES}

Ashenbaum, B. (2010). The twenty-minute just-in-time exercise. Decision Sciences Journal of Innovative Education, 8(1), 269-274. doi:10.1111/j.1540-4609.2009.00255.x

Bonwell, C. C., \& Eison, J. A. 1991. Active Learning; Creating Excitement in the Classroom. ASHE-ERIC Higher Education Report No. 1. Washington, D.C.: The George Washington University, School of Education and Human Development. Accessed August 15, 2020, available at https://files.eric.ed.gov/fulltext/ED336049.pdf.

Brau, R. I., Gardner, J. W., Webb, G. S., \& McDonald, J. K. (2019). Teaching plan-do-study-act (pdsa) in a supply chain context: A paper football in-class activity. Decision Sciences Journal of Innovative Education, 17(1), 6-32. doi:10.1111/dsji.12171

Calavita, N., \& Krumholz, N. (2003). Capturing the public interest:Using newspaper op-eds to promote planning in conservative times. Journal of Planning Education and Research, 22(4), 400-406. doi:10.1177/0739456x03022004006

Duke University. (2019). Writing effective op-eds - communicator toolkit. Accessed September 23, 2019, available at https://commskit.duke.edu/writing-media/writing-effective-op-eds/

Ellis, S. C., Goldsby, T. J., Bailey, A. M., \& Oh, J.-Y. (2014). Teaching lean six sigma within a supply chain context: The airplane supply chain simulation. Decision Sciences Journal of Innovative Education, 12(4), 287-319. doi:10.1111/dsji.12043

Erzurumlu, S. S., \& Rollag, K. (2013). Increasing student interest and engagement with business cases by turning them into consulting exercises. Decision Sciences Journal of Innovative Education, 11(4), 359-381. doi:10.1111/dsji.12019

Hall, J. C., \& Podemska-Mikluch, M. (2015). Teaching the economic way of thinking through op-eds. International Review of Economics Education, 19, 13-21. doi:https://doi.org/10.1016/j.iree.2015.05.002

Hall, T. (2013). Op-ed and you, Opinion. The New York Times. Accessed August 15, 2020. Available at https://www.nytimes.com/2013/10/14/opinion/op-ed-and-you.html

Hill, S., \& Baker, E. (2016). An active learning exercise for product design from an operations perspective. Decision Sciences Journal of Innovative Education, 14(3), 273-284. doi:10.1111/dsji.12101

Khansari, P. S., \& Coyne, L. (2018). An innovative addition to team-based-learning pedagogy to enhance teaching and learning: Students' perceptions of team exams. Curr Pharm Teach Learn, 10(1), 90-95. doi:10.1016/j.cptl.2017.09.009 
Kingston, L. N., MacCartney, D., \& Miller, A. (2014). Facilitating student engagement: Social responsibility and freshmen learning communities. Teaching \& Learning Inquiry: The ISSOTL Journal, 2(1), 63-80. doi:10.2979/teachlearninqu.2.1.63

Kock, N., Verville, J., \& Garza, V. (2007). Media naturalness and online learning: Findings supporting both the significant-and no-significant-difference perspectives. Decision Sciences Journal of Innovative Education, 5(2), 333-355.

Kovach, J. V., Miley, M., \& Ramos, M. A. (2012). Using online studio groups to improve writing competency: A pilot study in a quality improvement methods course. Decision Sciences Journal of Innovative Education, 10(3), 363-387. doi:10.1111/j.1540$\underline{4609.2012 .00349 . x}$

Li, N., Marsh, V., \& Rienties, B. (2016). Modelling and managing learner satisfaction: Use of learner feedback to enhance blended and online learning experience. Decision Sciences Journal of Innovative Education, 14(2), 216-242. doi:10.1111/dsji.12096

Michaelsen, L. K., \& Sweet, M. (2008). The essential elements of team-based learning. New directions for teaching and learning, 2008(116), 7-27.

Miles, M. B., \& Huberman, M. A. (1994). Qualitative data analysis: An expanded sourcebook. Thousand Oaks, CA: Sage.

Omang, J. (2008). Ten steps to writing an op ed.September 27, 2019 Retrieved from http://www.inims.illinois.edu/images/MemberResources/TenStepsWritingOpEd.pdf

Özpolat, K., Chen, Y., Hales, D., Yu, D., \& Yalcin, M. G. (2014). Using contests to provide business students project-based learning in humanitarian logistics: Psaid example. Decision Sciences Journal of Innovative Education, 12(4), 269-285. doi:10.1111/dsji.12044

Parmelee, D. X., \& Michaelsen, L. K. (2010). Twelve tips for doing effective team-based learning (tbl). Medical Teacher, 32(2), 118-122. doi:10.3109/01421590903548562

Prince, M. (2004). Does active learning work? A review of the research. Journal of engineering education, 93(3), 223-231.

Poronnik, P., \& Moni, R. W. (2006). The opinion editorial: Teaching physiology outside the box. Advances in Physiology Education, 30(2), 73-82. doi:10.1152/advan.00075.2005

Salemi, M. K. (2002). An illustrated case for active learning. Southern Economic Journal, 68(3), 721-731. doi: $10.2307 / 1061730$

Schneller, A. J. (2016). Writing letters to the editor to promote environmental citizenship and improve student writing. In Learner-centered teaching activities for environmental and sustainability studies (pp. 293-299): Springer. 
Ryan, R. M. \& Deci, E. L. (2018). Intrinsic motivation inventory (IMI). Accessed August 15, 2020, available at http://selfdeterminationtheory.org/intrinsic-motivation-inventory/

Socolow, M. J. (2010). A profitable public sphere: The creation of the new york times op-ed page. Journalism \& Mass Communication Quarterly, 87(2), 281-296. doi:10.1177/107769901008700204

Stansbury, J. A., \& Earnest, D. R. (2017). Meaningful gamification in an industrial/organizational psychology course. Teaching of Psychology, 44(1), 38-45. doi: $10.1177 / 0098628316677645$

Sun, J., Flores, J., \& Tanguma, J. (2012). E-textbooks and students' learning experiences. Decision Sciences Journal of Innovative Education, 10(1), 63-77. doi:10.1111/j.15404609.2011.00329.x

Sweet, M., \& Michaelsen, L. K. (2012). Team-based learning in the social sciences and humanities : Group work that works to generate critical thinking and engagement (1st ed.. ed.). Sterling, Va.: Stylus Pub.

The New York Times (1970, September 21). Op. Ed. Page. The New York Times. Retrieved from https://www.nytimes.com/1970/09/21/archives/op-ed-page-78167380.html

Wentzel, K. R. (1991). Social competence at school: Relation between social responsibility and academic achievement. Review of Educational Research, 61(1), 1-24. doi: $10.3102 / 00346543061001001$

Wilson, H. (1989). The craft of qualitative analysis. Research in nursing, 452-499.

Yin, R. K. (2017). Case study research and applications: Design and methods: Thousand Oaks, California: Sage. 


\section{APPENDICES}

APPENDIX A. OP-ED GRADING RUBRIC.

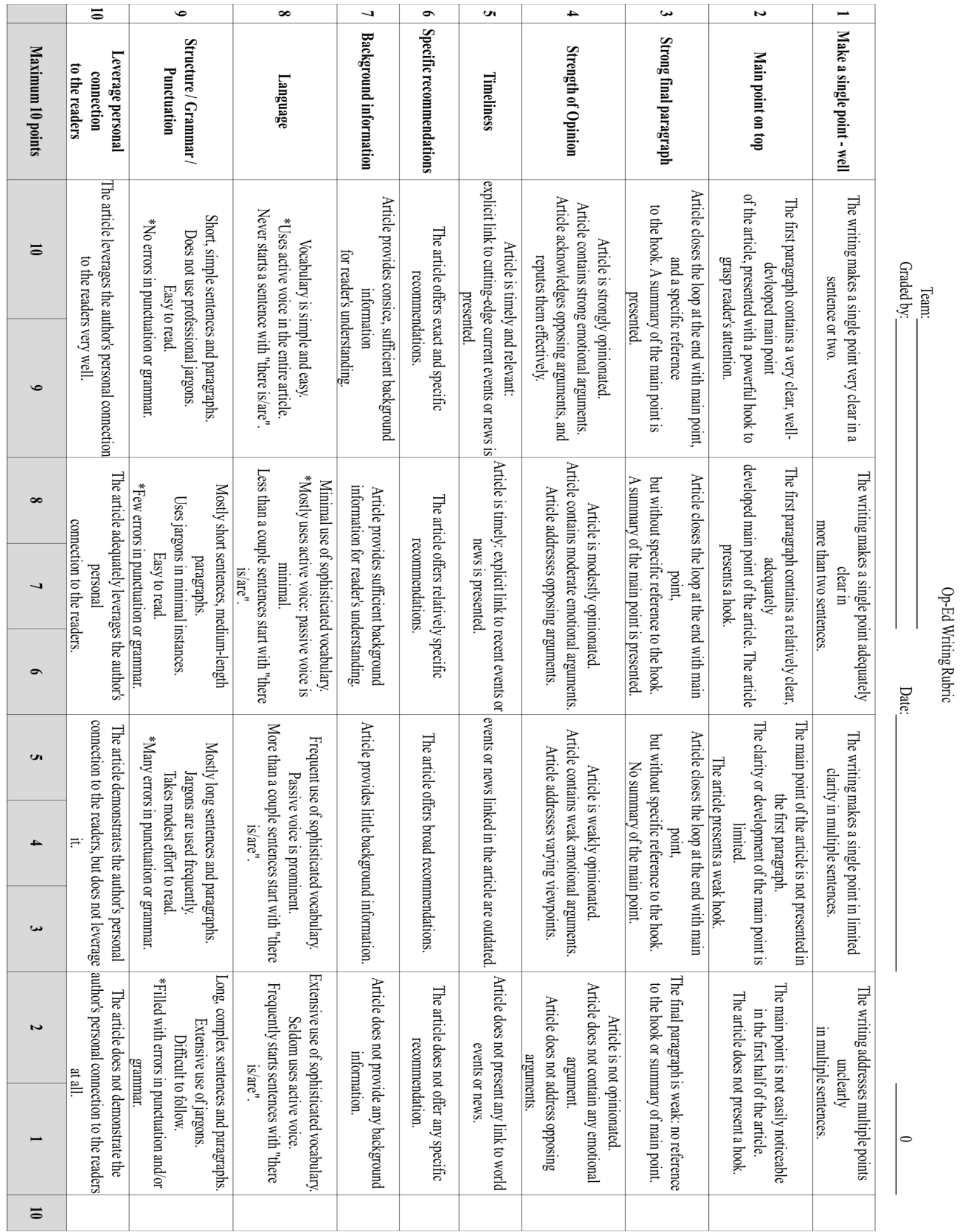




\section{APPENDIX B. FIRST DRAFT GENERAL FEEDBACK BY TA.}

\section{Op-eds First Feedback + Second Draft Deadline + Some Tips}

Hello guys,

I replied to your submission e-mails with my feedback. Download the file, and you will see my comments on the Word document.

As I specified in the reply e-mail, please work on improving your manuscripts with your team and submit a second draft.

The deadline for the second draft submission is Wednesday, April 10, by 5:00 PM.

Many of you started your approach by extending your research presentation into writing. This resulted in many manuscripts reading like informative journalism articles, commonly found on internet news media such as VOX and Huffington Post. This is not our goal. Dedicate less space on laying out facts and information, and more on your argument, your recommendations for action on the regional, state, or national level. This also resulted on weak, or lack of, core argument. Again, this is an opinion piece, so you have to move from information to recommendation. Always think about what must be done here, in Rhode Island or the United States, and why your readers should care or be concerned.

Also, I noticed not many manuscripts employed a hard-hitting hook in the intro paragraph. This is really important, because it sets the baseline of your op-ed in the minds of the readers, and it will retain the reader through the entire article. Also, in the last paragraph, loop back to the intro hook to complete the article. An easy approach would be to look for any news on recent events or significant development, depictions in movies or TV, or presenting a hypothetical scenario that is rather shocking. Many other approaches may be taken, but you want your first paragraph to be impactful.

When you've written your second manuscript, proofread for errors and typos before submission. I'd like to dedicate more time and energy in giving you practical guidance than in correcting writing errors.

Also, please use the file naming structure as follows: 001_Topic_Submission02.

Best,

Your TA

\section{APPENDIX C. SECOND DRAFT GENERAL FEEDBACK BY TA.}

\section{Op-ed Second Draft Feedback, Final Draft Deadline, and Preparation for Newspaper} Submission

Hello Class,

I was glad to see a lot of good progress.

Still, more work is needed to move on from laying down information to identifying problem areas and making calls for action with solutions.

Some common areas for improvement: 
1. The first paragraph. If this is the only paragraph I read, I should still very well be able to understand your whole article. It needs to open with a hook, identify problem area, and provide the core of your solutions and suggestions. All other pertinent information can come in the following paragraphs as a supplement. Again, DO NOT wait until later in the article to present your arguments and solutions.

2. Be very specific with your suggestions and solutions.

3. Too much information or detail hurts. Only mention necessary details briefly and move on to what YOU think should be done. Again, this is an opinion piece, not informative journalism. Any information or detail MUST have direct effect of supporting your argument and solutions.

Work with your team to improve your manuscript, and submit a third and FINAL draft by Tuesday, April 16, 5 PM. Make sure your file name is structured as follows: 01_(your topic)_Final_Draft. Editing from the feedback file would be easier.

When you submit the final draft to me, in the e-mail, state two newspapers your team would like to target for publication - make at least one of them a local newspaper. I will also provide feedback on this.

Refer to the following list:

Providence Journal: https://www.providencejournal.com/

Providence Business News: https://pbn.com/

The Call of Woonsocket: https://www.woonsocketcall.com/

Southern RI Newspapers: https://www.ricentral.com/

The Newport Daily News: https://www.newportri.com/

The Times of Pawtucket: https://www.pawtuckettimes.com/

The Westerly Sun: https://www.thewesterlysun.com/

Much more!!: https://en.wikipedia.org/wiki/List_of_newspapers_in_Rhode_Island

Best,

Your TA

\section{APPENDIX D. SAMPLE COVER LETTER TO EDITOR.}

\section{Dear Mr. Palpatine,}

We'd like to submit an opinion piece on The Republic Times.

We are Coruscant native, students of the College of Business at the Jedi Academy, currently majoring in supply chain management. The goal of this piece is to explain why, as students of business, we believe Coruscant should , and to urge the state government to take action.

Having conducted research on the topic, we believe that this could serve as a major opportunity/threat for Coruscant. It could . It has the potential to 
The piece is exclusive at $\underline{\mathbf{6 4 1}}$ words of text / $\underline{\mathbf{6 9 1}}$ words with title and bio notes, and has not been submitted to or published at any other media outlet. Happy to make any needed edits.

Thank you for your consideration,

Obi-wan Kenobi and Anakin Skywalker

obi-kenobi@jedi.rep, 222-111-2211, [home address]

thechosenone@jediacademy.rep, 111-222-4433, [home address]

[op-ed attached]

\section{APPENDIX E. INSTRUCTIONS FOR NEWSPAPER SUBMISSION BY TA.}

\section{Instructions for Submitting Your Op-ed to Editor}

Hello Class,

Great job in advancing your op-ed articles. I was happy to see many teams develop solid op-ed articles fit for publication.

Now that your manuscript should be ready, it's time to send it out to the newspaper editor. Closely observe the following instructions and use it as a checklist.

\section{The Op-ed Manuscript.}

Your op-ed manuscript Word document must contain ONLY the op-ed article: title, author names, main body, and bio note.

DO NOT include the cover letter, any date, course number, professor name, or edition. Also, make sure to remove any comments and markup. Go to File-Info-Check for IssuesInspect Document to identify anything you missed.

\section{The Target Newspaper.}

Submit to the newspaper with wider coverage first: national-regional-state-local-school. Both Providence Journal and Providence Business News are state-level papers.

If you are targeting these two papers, consider picking one for the first submission, and in case it doesn't get published, target a local paper for the second submission.

You may change your target for the second submission from the paper you indicated to me. In such case, consult me via e-mail.

\section{The Cover Letter to Editor.}

Research the name of the editor of your target newspaper and direct the cover letter to him/her. Formally address the editor by their last name or full name: Dear Mr. Stark, or Mrs. Mary Poppins. Don't say "Dear Tony Stark".

Pay attention to the word count. exclusive count is for only the main body of the article. the second count is for the whole document, including title and bio notes. 


\section{The submission E-mail.}

Your submission to the editor will be an e-mail, containing your cover letter and the manuscript. Your cover letter will be the body of the e-mail. Attach your manuscript as attachment.

Should you choose to paste your op-ed in the e-mail, you should indicate by saying [Op-ed pasted and attached] at the end of the cover letter, instead of just [Op-ed attached].

It's up to you whether to just attach or paste and attach your manuscript.

[CRITICALLY IMPORTANT] BCC my email in the recipient of the e-mail. DO NOT CC or include me as a main recipient.

This will be your submission proof to me.

5. The Submission Deadline.

Prepare according to the above instructions and send the e-mail to the editor by no later than 5PM on Thursday, April 18.

6. What to Do If Accepted.

In the case your manuscript is accepted for publication, forward the e-mail from the editor to me. Although publication is not a basis for your assessment, we will still celebrate.

May the Force be with you.

Your TA

\section{APPENDIX F: LIST OF PUBLISHED STUDENT OP-EDS.}

Self-driving trucks are coming. Providence Business News

Do you want to have to rely on a death to save your life? The Westerly Sun.

The blockchain could be a key cog in election reform efforts. The Westerly Sun.

A new NAFTA is being built, and we want big changes. The Westerly Sun.

We need reshoring, retraining programs. The Pawtucket Times.

Trade agreement deserves a second look. The Independent.

The Changing Arctic Sea Route and its New Opportunities. Seaview.

Reviving Churchill: Encouraging Arctic shipping in Canada's most prolific northern port. Seaview (accepted for Fall 2019 issue) - written by students of the Canadian university. 


\section{TABLES AND FIGURES}

Table 1: Topics research project and op-ed writing at the U.S. university.

\begin{aligned} & \hline 1 Uberization of last mile delivery \\ & 2 Blockchain and applications to SCM \\ & 3 Autonomous and electric trucks and implications on supply chains \\ & 4 Trans-Pacific Partnership Agreement (TPPA) and implications on global SCM \\ & 5 Rise of China and the One Belt One Road initiative \\ & 6 Industry 4.0: artificial intelligence and machine learning applications in SCM \\ & 7 Reshoring of U.S. manufacturing and foreign direct investment (FDI) in the U.S. \\ & 8 Additive Manufacturing (3D printing) and supply chain implications \\ & 9 The new Arctic Sea Route and global supply chain implications \\ & 10 Drone delivery in commercial and humanitarian supply chains \\ & 11 BREXIT: Britain's exit from the EU and implications on US supply chains \\ & 12 The new NAFTA and implications on North American supply chains \\ & \hline\end{aligned}

Table 2: Demographic breakdown of U.S. students.

\begin{tabular}{rrrr}
\hline Variable & & $n$ & $\%$ \\
\hline Gender & Male & 56 & $60.2 \%$ \\
& Female & 37 & $39.8 \%$ \\
Year & Senior & 49 & $52.7 \%$ \\
& Junior & 44 & $47.3 \%$ \\
Major & SCM & 40 & $43.0 \%$ \\
& Marketing & 33 & $35.5 \%$ \\
& General business management & 11 & $11.8 \%$ \\
& Global business management & 6 & $6.5 \%$ \\
& Management & 2 & $2.2 \%$ \\
& Others & 1 & $1.0 \%$ \\
\hline$N=93$ & & &
\end{tabular}

Table 3: Op-ed writing assignment milestones at the U.S. university.

\begin{tabular}{ccc}
\hline Milestone & Submission Due & Deliverable \\
\hline 1 & 9th week & First draft \\
2 & 11th week & Second draft \\
3 & 12th week & Final draft \\
4 & 13th week & First submission \\
5 & 14th week & Second submission \\
\hline
\end{tabular}


Table 4: Summary of student responses to the greatest takeaway.

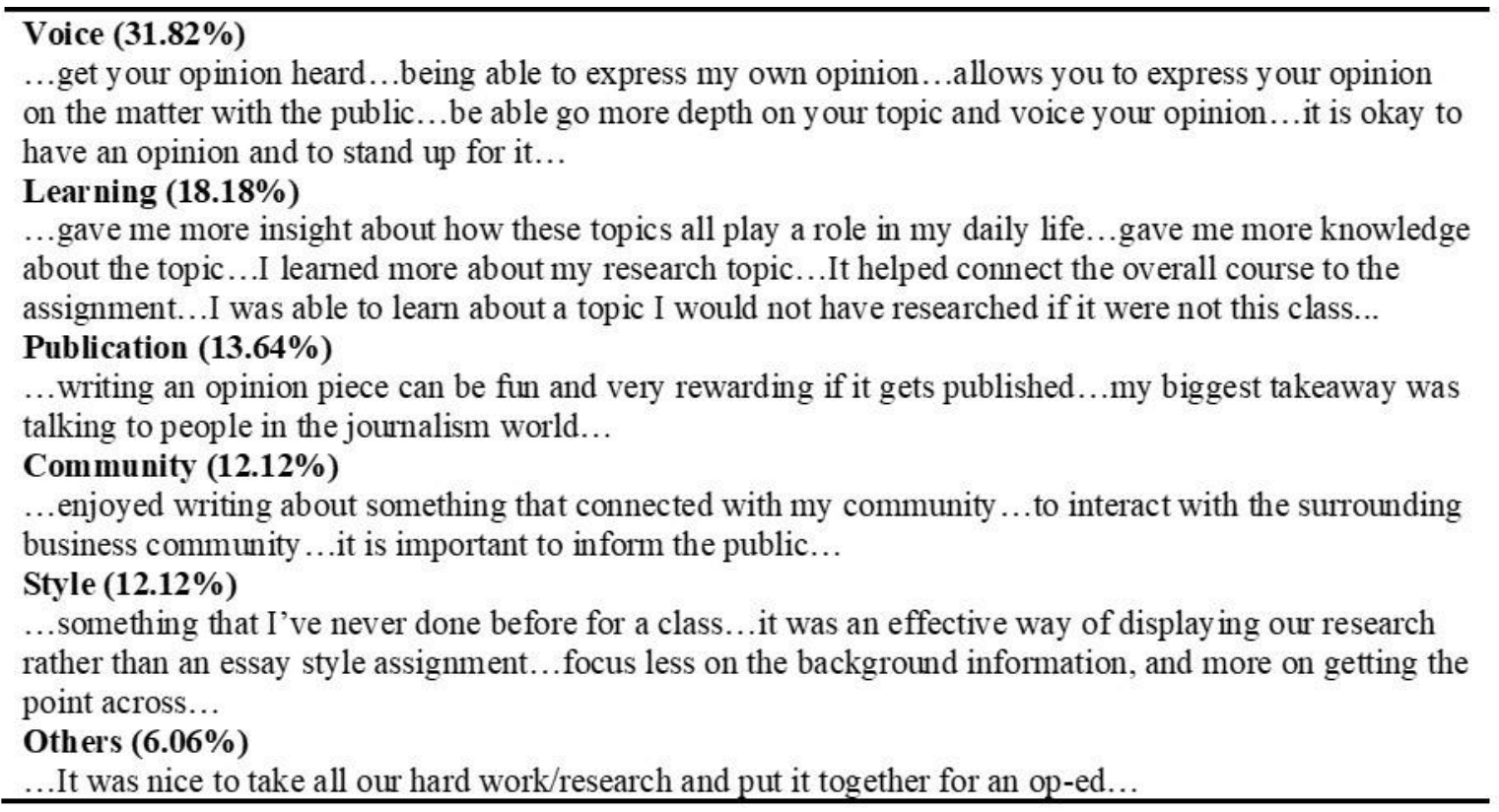

Table 5: Summary of student responses to greatest challenge.

\section{Teamwork (43.94\%)}

... all having own opinion on the topic and having to write one piece...merging opinions within the group...trying to have 4 people write an op-ed...having each group member write something different and make it flow nicely and all agree on the stated opinion...

\section{Opinion forming (13.64\%)}

...writing it the right way to make it more of an opinion than just all the facts...incorporating opinion vs. facts...try ing to make my topic about an opinion rather than explaining what it is...choosing a position to agree for or against... having an opinion...

\section{Style (12.12\%)}

...following the format and balancing info and opinion...focusing on a specific rather than a broad scale...finding the correct way to write it...getting everything we needed to say into only 700 words...

\section{Publication (12.12\%)}

...getting published...getting accepted by publisher...finding a newspaper to publish it... it is much harder to get op-ed published than I thought...

\section{Relevance (7.58\%)}

...our biggest challenge was including the most relevant information and condensing it...finding an example of an RI business that would benefit from investing in industry 4.0 ...finding a topic that is relevant to us and coming up with an interesting portion of it to write about...

\section{Iterative review process $(6.06 \%)$}

...there were a lot of revisions that need to be done...the feedback and making those changes...

\section{Others $(4.55 \%)$}

...it was hard to do after so many weeks of doing research project... 
Table 6: Distribution of student responses to the project assessment survey $(n=67)$

\begin{tabular}{|c|c|c|c|c|c|c|}
\hline Item & 1 & 2 & 3 & 4 & 5 & $4+5$ \\
\hline I am satisfied with the op-ed assignment. & $1 \%$ & $3 \%$ & $31 \%$ & $49 \%$ & $15 \%$ & $64 \%$ \\
\hline $\begin{array}{l}\text { I gained valuable experience from the op-ed } \\
\text { assignment. }\end{array}$ & $1 \%$ & $10 \%$ & $30 \%$ & $43 \%$ & $15 \%$ & $58 \%$ \\
\hline $\begin{array}{l}\text { Writing the op-ed improved my understanding on } \\
\text { the research topic. }\end{array}$ & $1 \%$ & $16 \%$ & $19 \%$ & $48 \%$ & $15 \%$ & $63 \%$ \\
\hline $\begin{array}{l}\text { I think writing an op-ed is useful for retaining the } \\
\text { knowledge I learned through the research project. }\end{array}$ & $1 \%$ & $7 \%$ & $25 \%$ & $48 \%$ & $18 \%$ & $66 \%$ \\
\hline The op-ed assignment helped me to learn. & $1 \%$ & $13 \%$ & $33 \%$ & $45 \%$ & $7 \%$ & $52 \%$ \\
\hline $\begin{array}{l}\text { The op-ed assignment helped me learn more than } \\
\text { writing another course project report. }\end{array}$ & $0 \%$ & $22 \%$ & $22 \%$ & $51 \%$ & $4 \%$ & $55 \%$ \\
\hline The op-ed assignment was relevant to the course. & $6 \%$ & $7 \%$ & $19 \%$ & $40 \%$ & $27 \%$ & $67 \%$ \\
\hline $\begin{array}{l}\text { The op-ed assignment provided me with a } \\
\text { challenge. }\end{array}$ & $3 \%$ & $6 \%$ & $12 \%$ & $63 \%$ & $16 \%$ & $79 \%$ \\
\hline
\end{tabular}

Note. 5 -point Likert scale. $1=$ Strongly Disagree to $5=$ Strongly Agree .

Table 7: Demographic breakdown of Canadian students.

\begin{tabular}{crcc}
\hline Variable & & $n$ & $\%$ \\
\hline Gender & Male & 54 & $77.1 \%$ \\
& Female & 16 & $22.9 \%$ \\
Year & Senior & 17 & $24.3 \%$ \\
& Junior & 37 & $52.9 \%$ \\
& Sophomore & 14 & $20.0 \%$ \\
Major & Visiting students & 2 & $2.8 \%$ \\
& Logistics/SCM & 14 & $20.0 \%$ \\
& General management & 19 & $27.1 \%$ \\
& International business & 4 & $5.7 \%$ \\
& Marketing & 7 & $10.0 \%$ \\
& Finance & 3 & $4.3 \%$ \\
& Economics & 4 & $5.7 \%$ \\
& Human resource management/ & 5 & $7.1 \%$ \\
& industrial relationship & 7 & $10 \%$ \\
& Accounting & 7 & $10 \%$ \\
\hline$N=70$ & Others & 7 & \\
& & &
\end{tabular}


Figure 1: The frequency of positive and negative words, as categorized by "bing" lexicon.

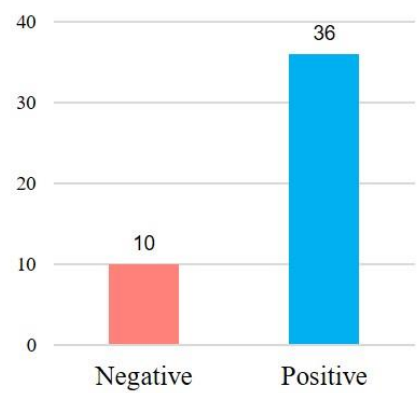

"bing" lexicon categories

Figure 2: The frequency of words associated with various emotions, as categorized by "nrc" lexicon.

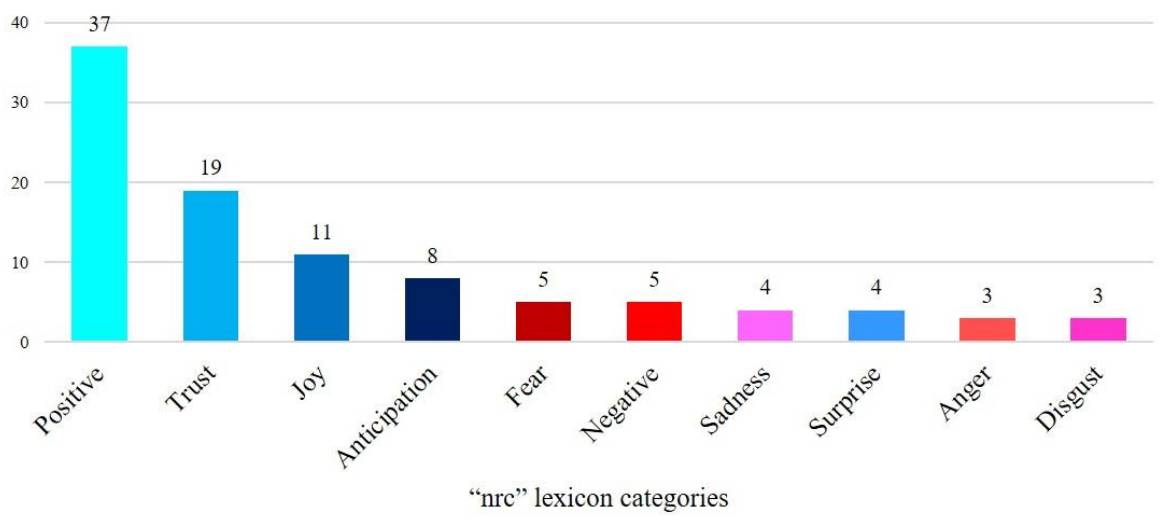

